\title{
Reproductive and larval biology of the sub-Antarctic hermit crab Pagurus comptus reared in the laboratory
}

\author{
Gustavo A. Lovrich* ${ }^{\ddagger}$ and Sven Thatje ${ }^{\dagger}$ \\ *Centro Austral de Investigaciones Científicas (CADIC), (9410) Ushuaia, Argentina. ${ }^{\dagger}$ National Oceanography Centre, Southampton, \\ School of Ocean and Earth Science, University of Southampton, European Way, Southampton, SO14 3ZH, UK. \\ ${ }^{\ddagger}$ Corresponding author, e-mail: lovrich@tierradelfuego.org.ar
}

\begin{abstract}
Fecundity, hatching rhythm, and the planktotrophic larval development of the hermit crab Pagurus comptus from sub-Antarctic waters of the Beagle Channel (Tierra del Fuego) were studied under controlled laboratory conditions of temperature, light cycle, food supply, and salinity. Fecundity was low, ranging from 134 to 848 eggs per female (cephalotoraxic shield length, SL, 2.3-5.0 mm). Hatching observed in the laboratory ranged from 6 to $30 \mathrm{~d}$. The larval development was studied in laboratory cultures fed with Artemia sp. nauplii and kept at constant $7.0 \pm 0.5^{\circ} \mathrm{C}$. Larvae invariably passed through four zoeal instars and one megalopa stage. Mean durations of the zoeal stages I to IV were 14.3 $\pm 1.8,16.7 \pm 4.6,23.2 \pm 6.5$, $33.4 \pm 9.2 \mathrm{~d}$, respectively. Combined with the $43.8 \pm 5.6 \mathrm{~d}$ recorded for the survived megalopae, we suggest that the complete larval development lasts about four months. Starved larvae, on average, survived for $22 \pm 8.1 \mathrm{~d}$ (maximum $38 \mathrm{~d}$ ) by far exceeding the zoea I duration in fed larvae, but did not reach the moult to the zoea II stage. Unlike other sub-Antarctic decapods, which show a tendency towards abbreviated or endotrophic larval developments at high latitudes, hermit crabs, at their southernmost distributional limit on Earth, show an extended and fully planktotrophic larval development and thus need to synchronize larval release with short periods of high primary production.
\end{abstract}

\section{INTRODUCTION}

Our knowledge on the biology of hermit crabs in high southern latitudes is very limited. Until recently, information only consisted of specific records of the four pagurid species present in the sub-Antarctic marine realm off South America (Boschi et al., 1992; Spivak, 1999; Retamal, 2000; for review see Gorny, 1999). Information on pagurid larval development is limited to Pagurus exilis (Scelzo \& Boschi, 1969), a subtropical species associated with the Brazil current that occurs off Rio de Janeiro $\left(23^{\circ} 06^{\prime} \mathrm{S} 43^{\circ} 11^{\prime} \mathrm{W}\right)$ south to Bahía Blanca $\left(39^{\circ} 16^{\prime} \mathrm{S}\right.$ $61^{\circ} 50^{\prime} \mathrm{W}$ ) (Spivak, 1999; Cervellini, 2001). Pagurus comptus (White, 1847) occurs in both Atlantic and Pacific sides off the southern tip of South America, north to Coquimbo, Chile $\left(30^{\circ} \mathrm{S} 71^{\circ} 20^{\prime} \mathrm{W}\right)$ and Montevideo, Uruguay $\left(35^{\circ} \mathrm{S}\right.$ $53^{\circ} 10^{\prime} \mathrm{W}$ ), respectively (Retamal, 2000). In the Beagle Channel, P. comptus is the only hermit crab inhabiting this area. It occurs principally in shallow waters, i.e. $<40 \mathrm{~m}$ depth at an average density of $93( \pm 294)$ individuals $x$ $10,000 \mathrm{~m}^{-2}$ (Pérez-Barros et al., 2004). Highest abundances occur associated with the holdfast of the kelp Macrocystis pyrifera, averaging 30 individuals $\times \mathrm{kg}$ holdfast $^{-1}$ and peaking at $\sim 600$ individuals $\times \mathrm{kg}$ holdfast $^{-1}$ (Brusca et al., 2000). A second species, P. forceps, has been occasionally found in sub-Antarctic waters (Boschi et al., 1992; Gorny, 1999; Lovrich et al., 2005) but never in the Beagle Channel. Pagurus spp. larvae occur in the plankton between September and December (Lovrich, 1999; Thatje et al., 2003). Previous studies on larval distribution did not identify to species level, because adequate larval descriptions are so far lacking (Scelzo, 1976; Bacardit, 1986; Wehrtmann \& Baez, 1997; Lovrich, 1999).
In this article, we document the reproductive biology of the hermit crab Pagurus comptus from the southernmost distributional limit of this family on Earth, in subAntarctic coastal waters of the Beagle Channel, by describing its egg-carrying period, fecundity, hatching rhythms, and the larval development under conditions of food supply versus starvation. The reproductive biology of $P$. comptus is discussed in combination with ecological and environmental factors prevailing in the sub-Antarctic, which might have contributed to set biogeographical limits in hermit crab distribution. Despite physiological considerations, ecological constraints prevailing from the harsh sub-polar environment might as well contribute to an understanding of the absence of hermit crabs from the polar seas.

\section{MATERIALS AND METHODS}

Sampling and maintenance of ovigerous females

For the study of larval development and hatching rhythm, living ovigerous females of Pagurus comptus were caught at about 15 to $30 \mathrm{~m}$ depth in the Beagle Channel $\left(54^{\circ} 53^{\prime} \mathrm{S} 68^{\circ} 17^{\prime} \mathrm{W}\right)$ in August 2002, using an inflatable dinghy equipped with an epibenthic trawl $(1.7 \mathrm{~m}$ mouth width, net with $1 \mathrm{~cm}$ mesh size). The trawl is designed to operate from onboard a small boat (see Tapella et al., 2002). For the study of fecundity, additional ovigerous females were obtained from monthly trawl samples taken in 1999 and 2000 (see Tapella et al., 2002; Pérez-Barros et al., 2004) and from holdfasts of the kelp Macrocystis pyrifera at about $10 \mathrm{~m}$ depth. Because female $P$. comptus occurred alternatively at different months in 1999 and 2000 and 


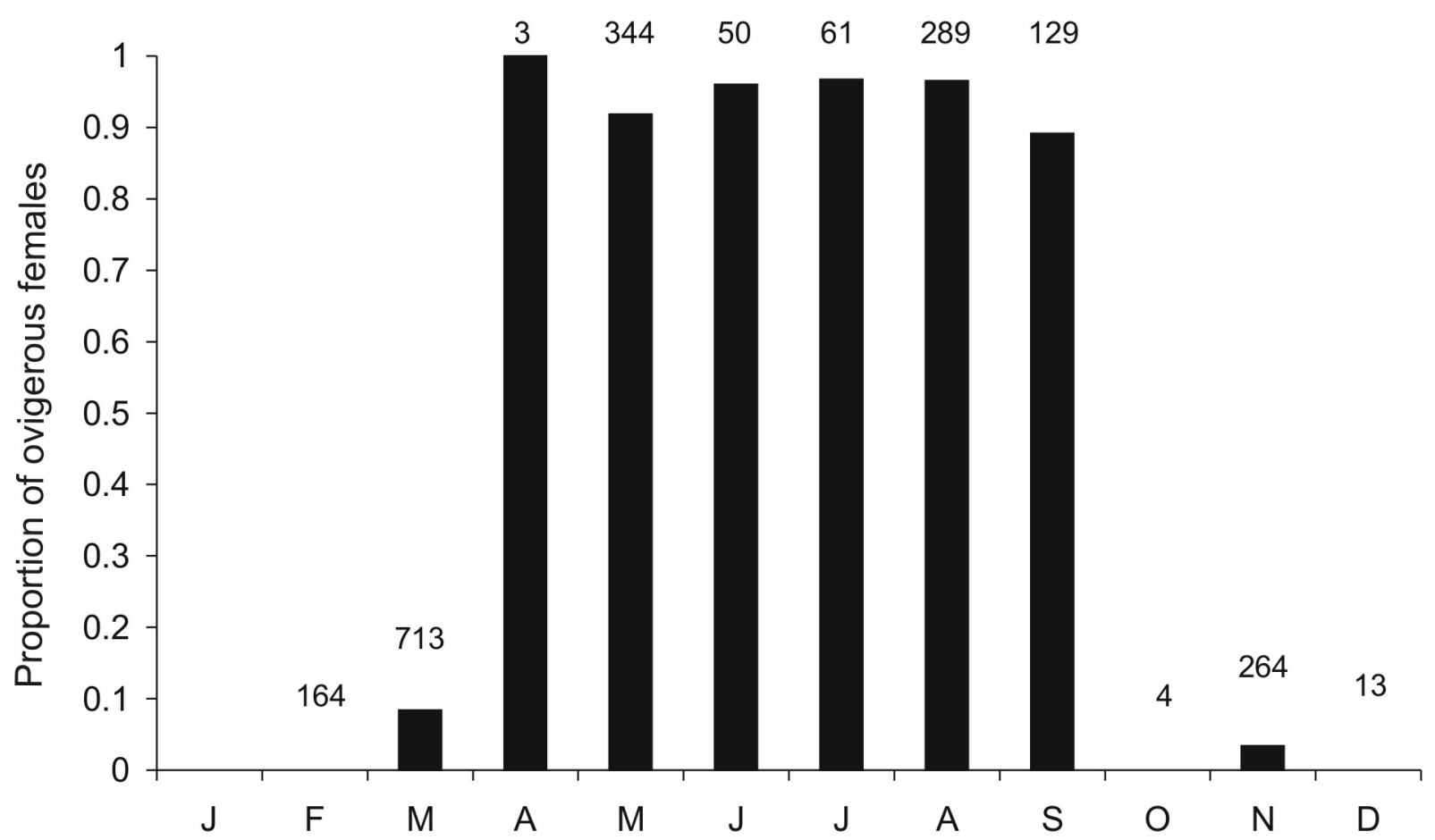

Figure 1. Pagurus comptus. Proportion of ovigerous females in the Beagle Channel during 1999 and 2000. Numbers above bars indicate the female sample size; no samples were taken in January. Monthly data from both years were combined.

hatching of larvae takes place only throughout southern spring (Lovrich, 1999), data of ovigerous females were pooled for both sampling years. For the study of fecundity all hermit crabs were fixed and preserved in $4 \%$ formalin buffered seawater.

Maintenance of ovigerous females and rearing of larvae took place in the local institute 'Centro Austral de Investigaciones Científicas' (CADIC) in Ushuaia, Tierra del Fuego (Argentina), in an acclimated room under constant temperature conditions $\left(7.0 \pm 0.5^{\circ} \mathrm{C}\right)$, salinity (30 psu), and artificial 12:12 h light/dark rhythm. The ovigerous hermit crabs obtained from the field and bearing advanced (eyed) embryos close to hatching were kept individually in flasks of 2-l water content. Water was changed every second day and food (commercial TETRA AniMin flakes for aquaristics, TetraWerke, Germany) was given twice a week.

\section{Larval rearing}

Hatched larvae were sampled every morning and collected from the bottom of the aquaria using glass pipettes. Hatched larvae and lost eggs of nine individually maintained females were counted. Forty-eight larvae hatched from a single Female D on 13 and 14 September 2002 were randomly selected and transferred into individual rearing cups with about $100 \mathrm{ml}$ seawater. Every second day, water was changed and food (Artemia sp. nauplii; Argent Chemical Laboratories, USA) was supplied. An additional rearing consisted of larvae from the same female $(\mathrm{N}=48)$ that were kept under starvation conditions. All larvae were checked daily for dead or moulted individuals. The appearance of exuvia was used to distinguish between the different stages of larval development.

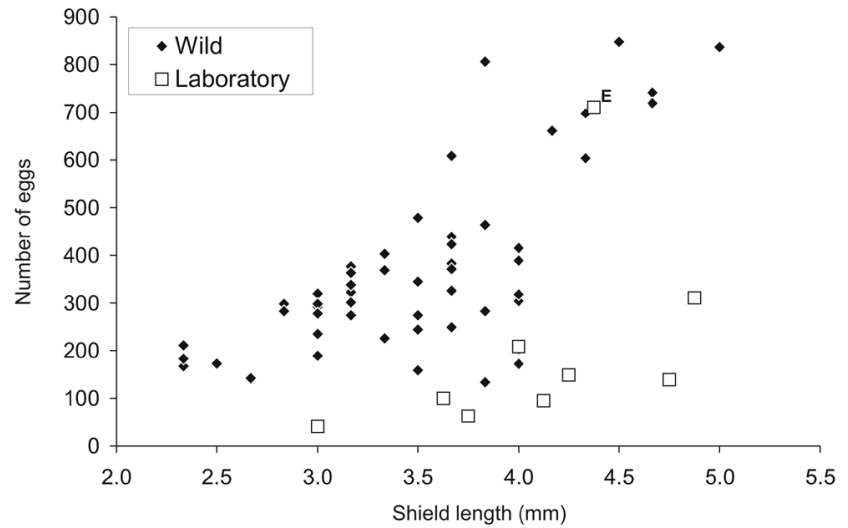

Figure 2. Female fecundity in Pagurus comptus from the Beagle Channel. Closed diamonds correspond to females obtained from the holdfasts of the kelp Macrocystis pyrifera, and open squares represent the sum of hatched larvae and lost eggs per female maintained in individual aquaria and caught in August 2000 with a trawl net. ' $E$ ' indicates the female from which larvae were used in this study.

\section{Estimation of fecundity}

The term fecundity is herein considered as the number of eggs per clutch. For the calculation of the clutch size/ number of eggs, pleopods with attached eggs were removed from each female by cutting the pleopodal base. Eggs were directly counted. Fecundity in the individually kept females for the study of hatching patterns and larval development was inferred from the daily number of hatched larvae and egg losses. Female size was estimated as the cephalotoraxic shield length (SL) measured with an eyepiece at $1.67 \mathrm{~mm}$ precision. The relationship 

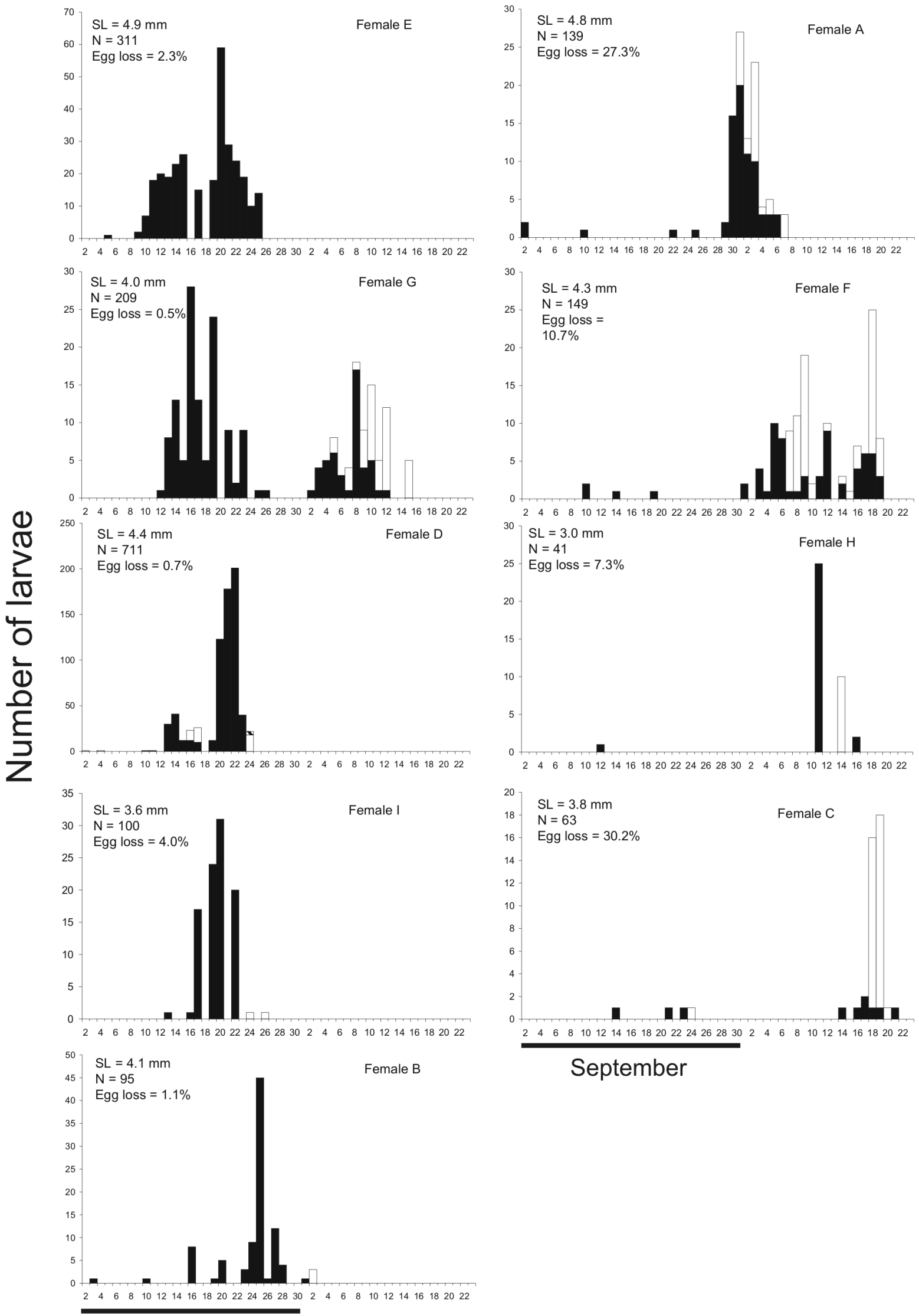

September

\section{Date}

Figure 3. Daily hatching rates in Pagurus comptus from the Beagle Channel in 2002. Bare bars represent pre-zoeae. Egg losses are not shown but are represented as the percentage of eggs lost with respect to total fecundity. SL is cephalotoraxic shield length; $\mathrm{N}$ is the fecundity. 


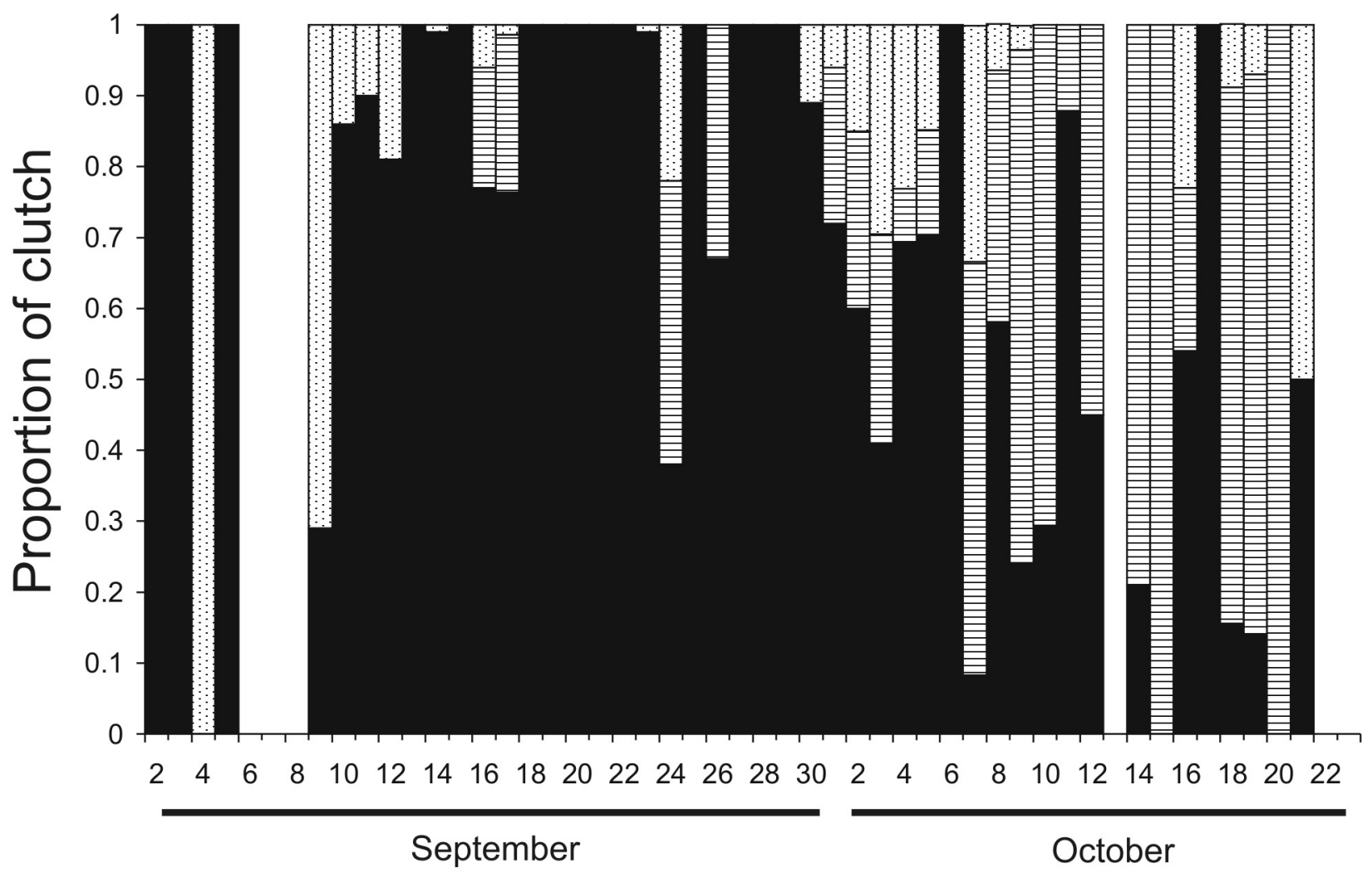

Figure 4. Daily hatching rates for nine female Pagurus comptus from the Beagle Channel, categorized by zoea (black bars), pre-zoea (hatched bars), and lost eggs (dotted bars). Sample size of each date is the sum of larvae hatched from all nine females (cf. Figure 3).

between fecundity and female size was analysed with a linear regression analysis (Sokal \& Rohlf, 1995), previously log-transforming data to achieve linearity. Differences between regression slopes were tested with an F-test (Sokal \& Rohlf, 1995).

\section{RESULTS \\ Fecundity}

Ovigerous females occurred mainly between April and September of 1999 and 2000 (Figure 1). Less than 10\% of ovigerous females occurred in March and November.

Fecundity of field-collected Pagurus comptus from the Beagle Channel was dependent on female size and varied between 134 and 848 eggs per female (Figure 2). The female $\log$ size explained $44 \%$ of the variation of the $\log$ number of eggs and followed a linear regression as follows: $\log \mathrm{N}$ eggs $=2.25 \log \mathrm{SL}-0.09$ (Figure 2; $F_{\text {regress }}=38.6$, $\left.P \ll 0.001, r^{2}=0.44\right)$. Fecundity from females kept for the experiments in the laboratory, i.e. the number of hatched larvae and lost eggs combined, was highly variable yet the $\log$ fecundity followed a linear regression: $\log \mathrm{N}$ eggs $=$ $4.13 \log \mathrm{SL}-0.36$ (Figure 2; $F_{\text {regress }}=38.6, \quad P=0.03$, $\left.r^{2}=0.52\right)$. Both regression slopes were significantly different $\left(F_{\text {eq.slopes }}=45.9, P \ll 0.001\right)$.

\section{Hatching rhythm}

Larvae always hatched at night, and hatching started about three weeks after the capture of ovigerous females. In the laboratory, hatching occurred from 2 September to
21 October, 2002, and extended through a period varying from 6 to $30 \mathrm{~d}$ per female (Figure 3). Hatching also varied among females: some females, e.g. females A and C, hatched their larvae during two almost discrete episodes whereas others showed hatching larvae in one continuous period or an even more patchy hatching distribution extending over time. For those females that hatched $>100$ larvae, the average percentage of total clutch size that hatched in a single night varied from 4 to $7.6 \%$ and peaked at 28\% (see female D, Figure 3 ). The number of hatched pre-zoeae increased towards mid-October (Figures 3 \& 4). The number of egg losses varied with female and contributed between 0.7 and $30.2 \%$ to the total clutch size. The first pre-zoea hatching occurred on 15 September, and proportion of hatched pre-zoeae increased thereafter (Figure 4). After 7 October, proportions of hatched pre-zoeae were always $>23 \%$ in all hatchings, and peaked 100\% twice (Figure 4).

\section{Larval development}

The larval development lasted about four months. Larval development comprises four zoeal stages and one megalopa. Zoeal mean durations were $14.3 \pm 1.8$, $16.7 \pm 4.6,23.2 \pm 6.5,33.4 \pm 9.2 \mathrm{~d}$, respectively (Figure 5). We recorded no metamorphosis to the crab I stage, yet megalopae, which had died after $105 \mathrm{~d}$ of larval development, had already reached the pre-moult stage, i.e. already showing the new telson detached from the old one and seen by transparency. The average developmental time of these non-moulted megalopae in pre-moult stage was $43.8 \pm 5.6 \mathrm{~d}$. Mortality, in the experiment with fed 


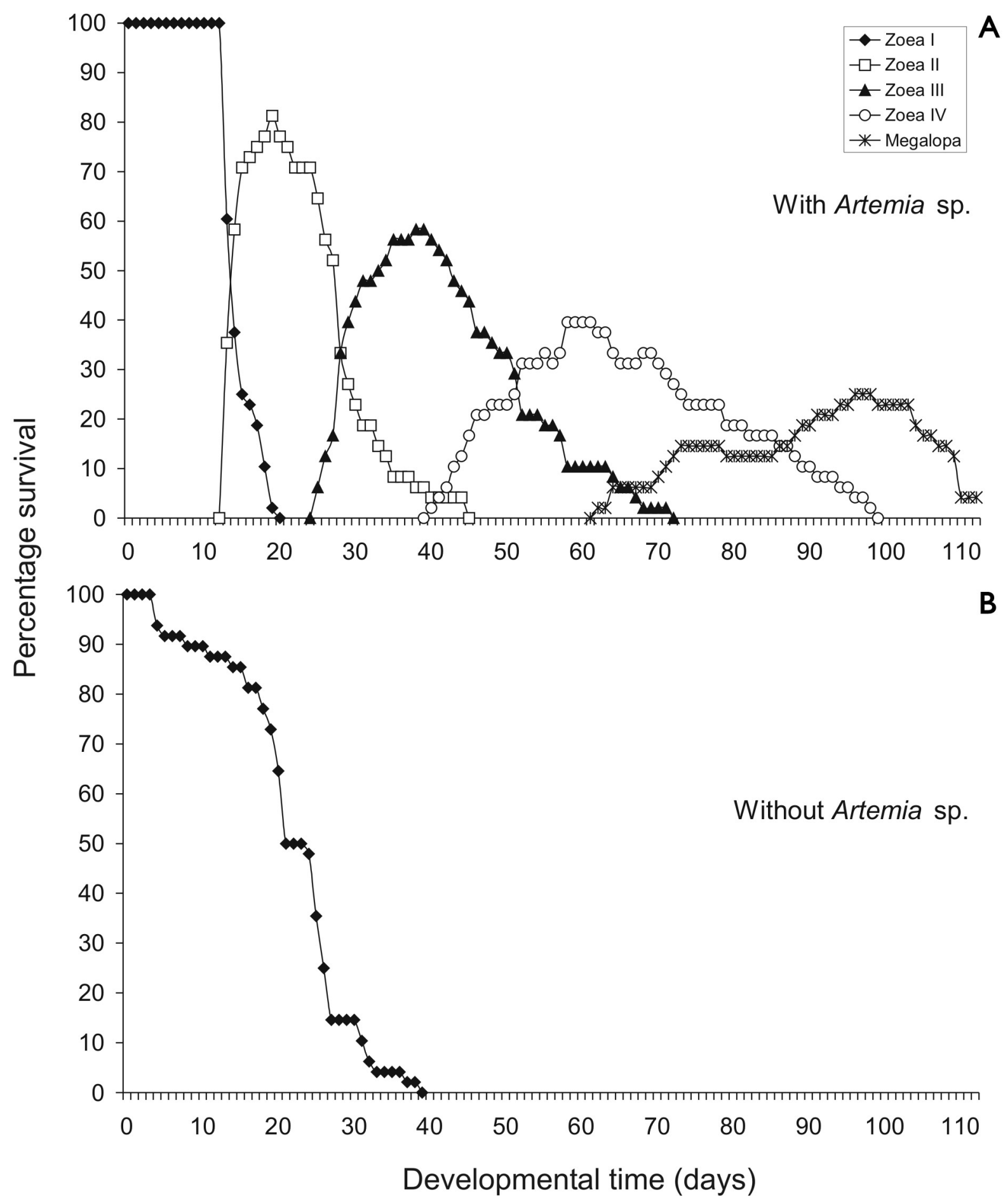

Figure 5. Pagurus comptus. Changes in the percentage of larval survival (N=48) throughout larval development. (A) Larvae with food (Artemia sp. nauplii); and (B) zoea I without food supply.

larvae, on average accounted for about $20 \%$ of larvae in each stage (Figure 5A).

Larvae kept under starvation conditions, i.e. without Artemia sp., did not reach the moult to the subsequent zoea II stage. The average survival time was $22.0 \pm 8.1 \mathrm{~d}$, although $10 \%$ of larvae survived up to one month, by far significantly exceeding the average developmental period of the zoea I instar in fed larvae (Student's $t$-test, $t=-6.44 ; \mathrm{df}=52 ; P \ll 0.001$; Figure 5B).

\section{DISCUSSION}

Decapod larvae contribute a great proportion to the spring meroplankton community in sub-Antarctic waters of the channel and fjord system off Tierra del Fuego (Lovrich, 1999; Thatje et al., 2003). Early life history strategies in sub-Antarctic decapods are highly diverse, ranging from fully planktotrophic larval developments, as, for example, in the present hermit crab 
Pagurus comptus, to tendencies of abbreviated planktotrophic larval developments in shrimp (Thatje et al., 2003) and even complete lecithotrophy is known in some anomuran lithodid crabs (Kattner et al., 2003). Overall, species with extended planktotrophic and thus actively feeding larvae at high latitudes need to optimize larval release with the first occurrence in phytoplankton production, notably in spring, in order to allow their larvae to complete development under the presence of food during short summers. Tendencies to abbreviate larval developments in decapods at high latitudes, have been frequently summarized as a consequence of latitudinal temperature adaptation (Clarke, 2003), in particular a mismatch of prolonged developmental times at low temperatures and short periods of food availability (Thatje et al., 2003). This, of course, is more evident in Antarctic seas, but the selective force behind this evolutionary temperature adaptation can yet be seen in a variety of ecological and physiological cold adaptations, which become already evident in the sub-Antarctic. Some shrimp genera with congeneric species in Antarctica (Campylonotus, Chorismus, Nematocarcinus) do already in the sub-Antarctic show the same reproductive pattern, e.g. an increase in energy investment into the single offspring on the cost of reduced fecundity. This suggests on an evolutionary pathway and low fecundity and fewer eggs per egg batch is an observation that unifies many high-latitudinal decapod species. However, the sub-Antarctic $P$. comptus does apparently not follow this tendency, and in addition does not show an abbreviation of its larval cycle at higher latitudes, which might indicate an additional phylogenetic constraint for temperature compensation in its reproductive pattern (Clarke, 2003). Although fecundity data in hermit crabs from lower latitudes are relatively scarce, comparison with congeneric species indicates that there might not be a decrease in fecundity with increasing latitude (Wada et al., 2000; Matellato et al., 2002; Iossi et al., 2005). Further investigation and especially biochemical study on energy content of eggs across latitude is urgently needed to further elucidate this question.

In our study, it should be recognized that the low fecundity of female hermit crabs kept in the laboratory compared with fecundity estimates in field collected ones is presumably due to their advanced egg batch and egg loss during embryogenesis. Field-collected pagurids used in this study showed egg batches in an early stage of development when egg loss is assumed to be lowest.

The proportion of ovigerous females collected from the field (Figure 1) suggests that embryo development in $P$. comptus at typical autumn/winter temperatures ranging from 4 to $6^{\circ} \mathrm{C}$ in the Beagle Channel (Anger et al., 2004) lasts between five and six months. Hatching is not completely synchronous in the studied population, but high starvation resistance by far exceeding usual zoea I duration in fed larvae, which is typical of some shrimp larvae (Wehrtmann, 1991; Thatje et al., 2003), could be interpreted as an ecological adaptation to a likely variability in food availability in early spring. The extended hatching mode presented here, is the first recorded in sub-polar pagurid crabs. However, extended hatching rhythms are known from sub-Antarctic shrimp (Campylonotus vagans, Thatje et al., 2004) and king crab (Lithodes santolla,
Paralomis granulosa, Thatje et al., 2003). Although the evidence is still scare for generalization, extended hatching rhythms have been discussed as an ecological adaptation to distribute the small offspring over longer periods of time, in order to reduce predation on the small offspring and/or as a result of physiological constraint (for discussion see Thatje et al., 2003).

As in other Pagurus spp., larval development of P. comptus comprises four zoeal stages and a megalopa (e.g. MacDonald et al., 1957; Goldstein \& Bookhout, 1972). We observed only dead prezoeae occurring towards the second half of the hatching period (Figure 4). As a general pattern, a prezoea survives and moults after a few minutes to hours of being hatched (Anger, 2001). In $P$. comptus the occurrence of prezoeae has been associated with detached eggs, mortality and the end of the hatching period. Therefore, we hypothesize that in $P$. comptus this stage is probably the way to loose unviable embryos rather than be an intermediate between the last embryonic and first zoea stages.

So, why are hermit crabs of the Beagle Channel the southernmost representatives of their kind on Earth? The absence of crabs from Antarctic seas was frequently discussed to be due to physiological constraints. Briefly, the inability of crabs to down-regulate high $\left[\mathrm{Mg}^{2+}\right]$ heamolymph concentrations below that of seawater, which should largely cause a paralyzing effect on any kind of behaviour (Frederich, 1999). Such a mechanism has been suggested to be efficient in shrimp explaining why this group thrives in Antarctica (Thatje et al., 2005). However, as the only crab family, anomuran lithodid crab were recently shown to be able to thrive under polar conditions as well, and one key to their existence in Antarctica was suggested to be their endotrophy and abbreviated development of larvae, which made them independent from the lack of planktonic food available, as well as extreme cold (Thatje et al., 2005). Lithodid crabs have been suggested to be closely related to hermit crabs (Cunningham et al., 1992; but see also McLaughlin \& Lemaitre, 1997; McLaughlin et al., 2004). However, one striking difference between Southern Ocean lithodids and hermit crabs is the extended larval planktotrophy in the latter. With a larval development lasting about four months in duration in P. comptus in the Beagle Channel (at constant $7^{\circ} \mathrm{C}$ in our laboratory rearing); a theoretical larval development at much lower temperatures typical of Antarctic seas would exceed years, as already suggested in extrapolated data on temperature tolerance from congeneric species (cf. Thatje et al., 2005). It is obvious that, despite possible physiological constraints, the mismatch in larval developmental duration and food availability alone, on an evolutionary scale should have selected against hermit crabs to sustain polar marine conditions. The reason for the lack of further endogenic (lecithotrophic) larval developments in marine pagurid crabs remains unknown, but might be related to their predominant shallow-water distribution and the principal availability of planktonic food. In the related lithodid crabs from the southern hemisphere, lecithotrophy is dicussed as a result of their evolution through the deep sea, which selected against planktotrophic larval stages (for discussion see Thatje et al., 2005). 
Our thanks are due to F. Díaz, M. Gutierrez, D. Aureliano, F. Tapella, P. Pérez-Barros, C. Romero and M. Brusca for field or laboratory assistance. This study is part of a bilateral cooperation project financed by the International Bureau of the German Ministry of Research (BMBF, Project no. IB Arg 99/002) and the Argentine Secretaría Nacional de Ciencia Tecnología, e Innovación Productiva (SECyT). Additional funding was provided by the Agencia de Promoción Científica y Técnica (PICTS 07-00471 and 01-10042 - SECyT).

\section{REFERENCES}

Anger, K., 2001. The biology of decapod crustacean larvae. Lisse: A.A. Balkema.

Anger, K., Lovrich, G.A., Thatje, S. \& Calcagno, J.A., 2004. Larval and early juvenile development of Lithodes santolla (Molina, 1782) (Decapoda: Anomura: Lithodidae) reared at different temperatures in the laboratory. Fournal of Experimental Marine Biology and Ecology, 306, 217-230.

Bacardit, R., 1986. Larvas de Crustacea Decapoda del Mar Patagónico Argentino, incluyendo el talud continental, adyacencias a la Tierra del Fuego e Islas Malvinas. Aspectos morfológicos, ecológicos y filogenéticos. $\mathrm{PhD}$ thesis, Universidad de Buenos Aires, Argentina.

Boschi, E.E., Fischbach, C.E. \& Iorio, M.I., 1992. Catálogo ilustrado de los Crustáceos Estomatópodos y Decápodos marinos de Argentina. Frente Marítimo Sección A, 10, 7-94.

Brusca, M., Lovrich, G.A., Romero, M.C., Calcagno, J.A. \& Tapella, F., 2000. Efectos del corte del dosel de Macrocystis pyrifera (Phaeophyta) sobre la fauna asociada a su grampón de fijación. In Proceedings of the IV Fornadas Nacionales de Ciencias del Mar, Puerto Madryn, 11-15 September 2000. pp. 44.

Cervellini, P.M., 2001. Variabilidad en la abundancia y retención de larvas de crustáceos decápodos en el estuario de Bahía Blanca, Provincia de Buenos Aires, Argentina. Investigaciones Marinas (Valparaíso), 29, 25-33.

Clarke, A., 2003. Costs and consequences of evolutionary temperature adaptation. Trends in Ecology and Evolution, 18, 573-581.

Cunningham, C.W., Blackstone, N.W. \& Buss, L.W., 1992. Evolution of king crabs from hermit crab ancestors. Nature, London, 355, 539-542.

Frederich, M., 1999. Ecophysiological limits to the geographical distribution of reptant decapod crustaceans in the Antarctic. Berichte zur Polarforschung, 335, 1-133.

Goldstein, B. \& Bookhout, C.G., 1972. The larval development of Pagurus pride Auxi Leach, 1814, under laboratory conditions (Decapoda, Paguridea). Crustaceana, 23, 263-281.

Gorny, M., 1999. On the biogeography and ecology of the Southern Ocean decapod fauna. Scientia Marina, 63, Suppl. 1, 367-382.

Iossi, C.L., Biagi, R. \& Mantelatto, F.L., 2005. Egg production and shell relationship of the hermit crab Pagurus brevidactylus (Anomura: Paguridae) from southern Brazil. Animal Biology, 55, 111-121.

Kattner, G., Graeve, M., Calcagno, J.A., Lovrich, G.A., Thatje, S. \& Anger, K., 2003. Lipid, fatty acid and protein utilization during lecithotrophic larval development of Lithodes santolla (Molina) and Paralomis granulosa (Jacquinot). Fournal of Experimental Marine Biology and Ecology, 292, 61-74.

Lovrich, G.A., 1999. Seasonality of larvae of Brachyura and Anomura (Crustacea, Decapoda) in the Beagle Channel, Argentina. Scientia Marina, 63, Suppl. 1, 347-354.

Lovrich, G.A., Romero, M.G., Tapella, F. \& Thatje, S., 2005. Distribution, reproductive and energetic conditions of decapod crustaceans along the Scotia Arc (Southern Ocean). Scientia Marina, 69, Suppl. 2, 183-193.
MacDonald, J.D., Pike, R.B. \& Williamson, D., 1957. Larvae of the British species of Diogenes, Pagurus, Anapagurus, and Lithodes (Crustacea, Decapoda). Proceedings of the Zoological Society of London, 128, 209-257.

Mantelatto, F.L.M., Alarcon, V.F. \& Garcia, R.B., 2002. Egg production strategies of the tropical hermit crab Paguristes tortugae from Brazil. Fournal of Crustacean Biology, 22, 390-397.

McLaughlin, P.A. \& Lemaitre, R., 1997. Carcinization in the Anomura - fact or fiction? I. Evidence from adult morphology. Contributions to Zoology, 67, 79-123.

McLaughlin, P.A., Lemaitre, R. \& Tudge, C.C., 2004. Carcinization in the Anomura - fact or fiction? II. Evidence from larval, megalopal and early juvenile morphology. Contributions to Zoology, 73, 165-205.

Pérez-Barros, P., Tapella, F., Romero, M.C., Calcagno, J.A. \& Lovrich, G.A., 2004. Benthic decapod crustaceans associated to captures of Munida spp. Decapoda: Anomura) in the Beagle Channel, Argentina. Scientia Marina, 68, 237-246.

Retamal, M.A., 2000. Decápodos de Chile. World Biodiveristy Database. CD-ROM Series. ETI-UNESCO.

Scelzo, M.A., 1976. Larvas de los crustáceos decápodos anomuros identificadas en las aguas marinas argentinas. Physis Sección A, 35, 37-45.

Scelzo, M.A. \& Boschi, E.E., 1969. Desarrollo larval del cangrejo ermitaño Pagurus exilis (Benedict) en laboratorio (Crustacea, Anomura, Paguridae). Physis, 29, 165-184.

Sokal, R.R. \& Rohlf, F.J., 1995. Biometry, the principles and practice of statistics in biological research. New York: W.H. Freeman \& Co.

Spivak, E., 1999. Los crustáceos decápodos del Atlántico sudoccidental $\left(25^{\circ}-55^{\circ} \mathrm{S}\right)$ : distribución y ciclos de vida. Investigaciones Marinas (Valparaíso), 25, 69-71.

Tapella, F., Lovrich, G.A., Romero, M.C. \& Thatje, S., 2002. Reproductive biology of the crab Munida subrugosa (Decapoda: Anomura: Galatheidae) in the Beagle Channel, Argentina. Fournal of the Marine Biological Association of the United Kingdom, 82, 589-595.

Thatje, S., Anger, K., Calcagno, J.A., Lovrich, G.A., Pörtner, H.O. \& Arntz, W.E., 2005. Challenging the cold: crabs reconquer the Antarctic. Ecology, 86, 619-625.

Thatje, S., Calcagno, J.A., Lovrich, G.A., Sartorio, F.J. \& Anger, K., 2003. Extended hatching periods in the Subantarctic lithodid crabs Lithodes santolla and Paralomis granulosa (Crustacea: Decapoda). Helgoland Marine Research, 57, 110-113.

Thatje, S., Lovrich, G.A. \& Anger, K., 2004. Egg production, hatching rates, and abbreviated larval development of Campylonotus vagans Bate, 1888 (Crustacea: Decapoda: Caridea) in subantarctic waters. Fournal of Experimental Marine Biology and Ecology, 301, 15-27.

Thatje, S., Schnack-Schiel, S. \& Arntz, W.E., 2003. Developmental trade-offs in Subantarctic meroplankton communities and the enigma of low decapod diversity in high southern latitudes. Marine Ecology Progress Series, 260, 195-207.

Wada, S., Kitaoka, H. \& Goshima, S., 2000. Reproduction of the hermit crab Pagurus lanuginosus and comparison of reproductive traits among sympatric species. Fournal of Crustacean Biology, 20, 474-478.

Wehrtmann, I.S., 1991. How important are starvation periods in early larval development for survival of Crangon septemspinosa larvae? Marine Ecology Progress Series, 73, 183-190.

Wehrtmann, I.S. \& Baez, P., 1997. Larvas y estadios tempranos de desarrollo de crustáceos decápodos de Chile: descripciones publicadas. Investigaciones Marinas (Valparaíso), 25, 263-276.

Submitted 2 December 2005. Accepted 4 May 2006. 